\title{
Temperature Effects on the Disease Reactions of Sunflower to Infection by Orobanche cumana
}

S. Sukno and J. M. Fernández-Martínez, Departamento de Mejora y Agronomía, Instituto de Agricultura Sostenible; and J. M. Melero-Vara, Departamento de Protección de Cultivos, Instituto de Agricultura Sostenible, CSIC, Apdo. 4084, 14080, Córdoba, Spain

\begin{abstract}
Sukno, S., Fernández-Martínez, J. M., and Melero-Vara, J. M. 2001. Temperature effects on the disease reactions of sunflower to infection by Orobanche cumana. Plant Dis. 85:553-556.

Three virulent populations (CU194, SE193, and SE194) of the parasitic plant Orobanche cumana were inoculated onto four lines (KA-41, J-8281, HA-89, and RHA-273) of sunflower (Helianthus annuus L.). Pots were transferred to growth chambers set at $15,19,23$, and $27^{\circ} \mathrm{C}$. Emergence of broomrape plants and infection incidence were determinants of disease reaction. All broomrape populations were pathogenic to the sunflower lines KA-41, HA-89, and RHA273 , although differences in virulence were found. At 15 to $23^{\circ} \mathrm{C}$, the populations of broomrape infected these three sunflower lines, but a delay in emergence of broomrape was found at $15^{\circ} \mathrm{C}$; whereas, at $27^{\circ} \mathrm{C}$, the level of infection was restricted. Only population CU194 infected the resistant line J-8281, with infection occurring mainly at 23 and $27^{\circ} \mathrm{C}$, but few broomrape plants emerged. Our results suggest that the effect of temperature on the host-parasite relationship is complex.
\end{abstract}

Additional keywords: differential lines, resistance genes

Broomrape (Orobanche cumana Wallr.) is a holoparasitic plant that causes severe yield losses in sunflower (Helianthus annuus L.) in areas around the Black Sea as well as in some areas of the Mediterranean basin $(4,6,9,12)$. Musselman (9) and Parker and Riches (12) reported that this species belongs to the complex of $O$. cernua Loefl., which has two subspecies, one with its host range within the Solanaceae and the other (O. cernua var. $c u$ mana) which is restricted to Asteraceae, mainly sunflower. The latter has been reconsidered as a separate, although closely related, species in recent studies (13). The rapid evolution of the parasite has led to the appearance of virulent populations that are able to attack the currently resistant sunflower lines (16). Broomrape races and race complexes can be characterized by the reaction on host differential lines. Vrânceanu et al. (17) established a set of five sunflower differ-

Corresponding author: J. M. Melero-Vara E-mail: cs9mevaj@uco.es

This research was supported by project AIR2-CT94-1500 and contract FAIR CT96-5028 from European Commission. This article includes a portion of the thesis by S. Sukno in partial fulfillment of the requirements for the Ph.D. degree.

Accepted for publication 7 February 2001.

Publication no. D-2001-0321-01R

(C) 2001 The American Phytopathological Society entials carrying five resistance genes, $O r_{1}$ to $O r_{5}$, and a universal susceptible host. These allow the identification of five physiological races designated as A to E.

Field observations have described the influence of planting time on the severity of infection and seasonal fluctuation in the attack of broomrape species, suggesting a temperature effect on the host-parasite interaction $(3,5,15)$. This temperature effect seems partly indirect through the influence of seasonal fluctuations on host phenology, which is a determinant for the infection processes in some pathosystems $(2,3)$. Moreover, although temperature is known to influence germination and radicle elongation of Orobanche spp., its effect on subsequent development of the parasitic seedlings has not been studied for $\mathrm{O}$. $\mathrm{Cu}$ mana (10).

Temperature seems to modify the sunflower-broomrape interaction; therefore, environmentally controlled experiments were conducted to determine the effect of temperature on the infection of sunflower lines differing in susceptibility to broomrape. The need for accurate growth chamber experiments to understand the relationship between temperature and the resistance of sunflower to O. cernua was recognized by Ish-Shalom-Gordon et al. (5). This information could be a first step in the recommendation of the appropriate planting dates for sunflower lines possessing different resistance genes. The interaction between temperature and populations of $O$. cumana from different geographical areas was also studied.

\section{MATERIALS AND METHODS}

Sunflowers included in the study consisted of two differential lines Kruglik-A41 (KA-41) and Jdanovski 8281 (J-8281), carrying the genes $O r_{1}$ and $O r_{2}$ for resistance to $O$. cumana, respectively; and the inbred lines RHA-273 and HA-89, released by the United States Department of Agriculture. The four lines were inoculated with three highly virulent populations of $O$. cumana (CU194, SE193, and SE194). Seed from these populations had been collected in the main growing areas of the crop in central (Cuenca, CU) and southern (Sevilla, SE) Spain 3 to 4 years before the experiments were conducted. Seed was collected in summer, at full maturity of broomrape plants, and stored in glass jars kept in the dark at room temperature. Inoculations were performed by transplanting 2-day-old sunflower seedlings into small pots with $250 \mathrm{~g}$ of a soil mixture (sand:silt, $1: 1, \mathrm{vol} / \mathrm{vol}$ ) uniformly infested with $25 \mathrm{mg}$ of broomrape seed $(8,11)$. Plants were incubated in growth chambers set at four different temperatures $(15 \pm 1,19 \pm 1,23 \pm$ 1 , and $27 \pm 1{ }^{\circ} \mathrm{C}$ ) under fluorescent light $(14 \mathrm{~h} /$ day photoperiod, with light intensity of $240 \mu \mathrm{mol} \mathrm{m} \mathrm{m}^{-2} \mathrm{~s}^{-1}$ ). Fluctuating temperatures were not considered in agreement with previous conclusions (2). After 2 weeks of incubation, plants were transferred into pots with $2 \mathrm{~kg}$ of soil mixture (peat moss:sand:silt, 2:2:1, $\mathrm{vol} / \mathrm{vol} / \mathrm{vol}$ ); fertilized with Osmocote Plus (N-P-K 15$11-13$ plus $2 \mathrm{MgO}$ plus micronutrients) at $2.5 \mathrm{~g} / \mathrm{kg}$ of soil and maintained at the same temperature until the end of the experiment. The number of emerged broomrapes was recorded at 11, 14, and 16 weeks after sowing for the plants incubated a $15^{\circ} \mathrm{C}$; at 10,11 , and 13 weeks for those incubated at 19 and $23^{\circ} \mathrm{C}$; and at 8 weeks after sowing, when plants initiated blooming, and at 11 and 13 weeks for plants incubated at $27^{\circ} \mathrm{C}$. Disease reactions were assessed by the average number of emerged broomrapes per sunflower plant, commonly referred to as degree of attack (a measure of severity of infection) and by the incidence of infected plants (17). At maturity, uprooted plants were carefully removed, with the intention of obtaining as much of the root system as possible. The roots were cleaned and broomrape nodules were observed for evaluation of percent incidence.

Plants from each sunflower line-broomrape population combination were ran- 
domly assigned to 13 randomized complete blocks within each chamber. A combined analysis of variance over temperature, based on a factorial design, was conducted with the data on degree of attack. The effect of the temperature was evaluated by orthogonal polynomial contrasts (Statistic Analytical Software, Roseville, MN). Significant differences between mean values of lines were evaluated by a test of least significant difference (LSD) at the $1 \%$ probability level. Interactions were ana-
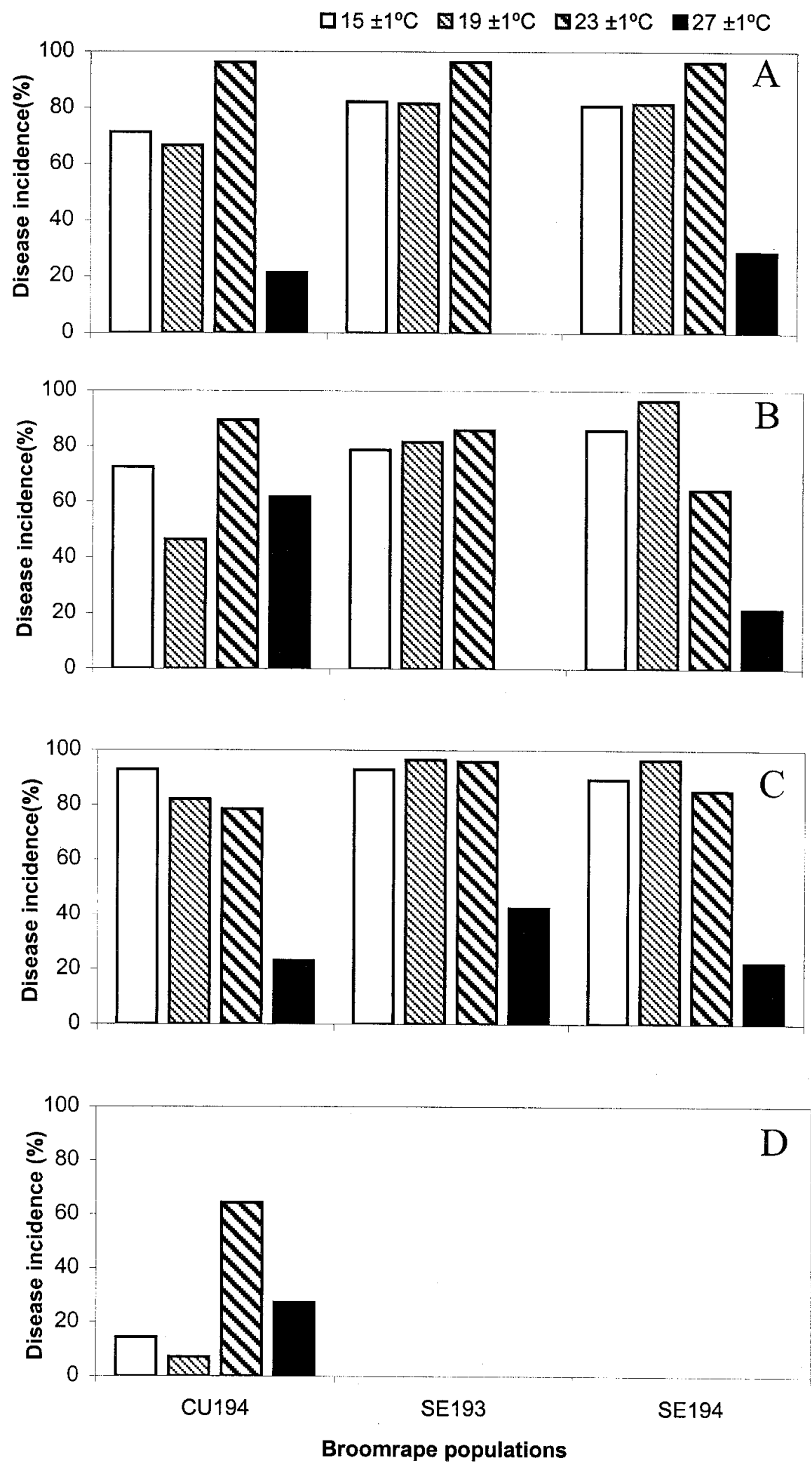

Fig. 1. Effect of temperature on the incidence of broomrape infection of four sunflower lines (A, KA41, B, HA-89, C, RHA-273, and D, J-8281) inoculated with three populations of Orobanche cumana.

lyzed by comparing the effects of incubation on sunflower lines at each temperature. The experiment was repeated twice, except for the incubation temperature of $27^{\circ} \mathrm{C}$.

\section{RESULTS}

The results of the two experiments on disease incidence and degree of attack were similar. Therefore, average values were calculated for the different treatments that were repeated in the two experiments.

All the populations of $O$. cumana tested were pathogenic to KA-41, HA-89, and RHA-273, but lower disease incidence was observed when CU194 was inoculated on HA-89 and incubated at $19^{\circ} \mathrm{C}$, as well as for sunflower line-broomrape population combinations that were incubated at $27^{\circ} \mathrm{C}$, with the exception of J-8281-CU194 (Fig. 1). Only population CU194, particularly at 23 and $27^{\circ} \mathrm{C}$ (Fig. 1), infected $\mathrm{J}-8281$. Infections achieved at this temperature consisted mainly of very small nodules from the attachments to host roots which did not develop to emerged broomrapes and, therefore, are not reflected in the degree of attack (Fig. 2). Disease incidence was lowest at $27^{\circ} \mathrm{C}$ except for population CU194, with lower disease incidence when J-8281 was incubated at 15 and $19^{\circ} \mathrm{C}$ (Fig. 1).

A delay in the emergence of broomrape at the lowest temperature $\left(15^{\circ} \mathrm{C}\right)$ was observed. However, final values of degree of attack at 16 weeks after sowing were similar to those reached after 13 weeks incubation at $19^{\circ} \mathrm{C}$, when sunflower plants incubated at both temperatures had a similar growth stage.

Temperature had a large effect on degree of attack except in the case of the resistant line J-8281. Regardless of the broomrape population, values of degree of attack in KA-41 were highest $(P=0.005)$ when incubation temperature was $19^{\circ} \mathrm{C}$. Line KA-41 was significantly $(P=0.03$ and 0.05) more susceptible to SE193 than to CU194, with significant $(P=0.004)$ differences between SE193 and the two other populations of broomrape tested only when incubated at $15^{\circ} \mathrm{C}$ (Fig. $2 \mathrm{~A}$ ).

Line HA-89 was significantly $(P=0.04$ and 0.009) less susceptible to CU194 than to SE193 and SE194. There was a linear effect of temperature on the susceptibility of HA-89 to broomrape population SE193. CU194 showed lower virulence than the other populations of $O$. cumana only at $19^{\circ} \mathrm{C}(P=0.04$ and 0.004 ; Fig. $2 \mathrm{~B})$.

As in the case of line HA-89, line RHA273 was less severely attacked by population CU194 than by the two other broomrape populations tested. At $23^{\circ} \mathrm{C}$, degree of attack on this line was significantly higher $(P=0.0001)$ when it was inoculated with SE193, whereas population CU194 was significantly less virulent when incubated at $19^{\circ} \mathrm{C}(P=0.0001)$.

Sunflower line J-8281 showed much lower degrees of attack than the other 
lines, regardless of the broomrape population, incubation temperature, and experiment considered. In this line, CU194 showed a significantly higher $(P=0.07$ and 0.04) degree of attack than the two other populations (Fig. 2D).

The degree of attack of populations CU194 and SE193 on KA-41 was higher than on the other lines tested when incubated at $19^{\circ} \mathrm{C}$, whereas that of CU194 on RHA-273 was highest at $15^{\circ} \mathrm{C}$ (Fig. 2). The degree of attack of SE194 on KA-41 at $23^{\circ} \mathrm{C}$ was higher $(P=0.0001)$ than on HA-89 and RHA-273 (Fig. 2).

\section{DISCUSSION}

Studies of distribution, virulence, and characterization of different populations of O. cumana using differential lines were carried out previously in Spain $(4,7,8)$. Susceptibility of KA-41 (the differential line carrying the gene $O r_{1}$ ), HA- 89 , and RHA-273 to the three broomrape populations tested and resistance of the differential line J-8281 (with $O r_{2}$ ) to populations SE193 and SE194 confirmed previous studies $(8,14)$. The moderately resistant reactions obtained with the differential line J-8281 when it was inoculated with broomrape population CU194 and incubated at 23 and $27^{\circ} \mathrm{C}$ also agree with other results (8). In contrast, this line showed a fully resistant reaction when incubated at other temperatures and when inoculated with SE193 and SE194 (Figs. 1 and 2), in agreement with the high resistance observed previously (8). This could be explained by a specific effect of temperature or genetic differences that may occur within a broomrape population (8).

Both seed germination and radicle elongation of $O$. cernua attacking tomato plants have an optimal temperature of 23 to $25^{\circ} \mathrm{C}$, with a sharp decrease at $28^{\circ} \mathrm{C}$ and higher temperatures (10). However, germination of $O$. cumana attacking sunflower was shown to be optimal at $20^{\circ} \mathrm{C} \mathrm{(3),} \mathrm{and} \mathrm{ger-}$ mination and attachment were both optimal at thermal regimes of 20 and 10 or 25 and $15^{\circ} \mathrm{C}$ (day and night, respectively), according to Sauerborn (15). Our results essentially agree with these, because highest severities were generally observed when incubation was at $19^{\circ} \mathrm{C}$, except for HA-89. In general, HA-89 had a higher degree of attack at $15^{\circ} \mathrm{C}$ and seemed to decrease as the temperature increased (Fig. 2B). This suggests that broomrape populations are able to infect sunflower at a wide range of temperatures below $27^{\circ} \mathrm{C}$, with variation depending on the sunflower linebroomrape population combination. Field observations of $O$. cumana parasitizing sunflower, not only in summer (which is the normal sunflower growing season in Spain) but also in winter (3), support the conclusions reported here.

Other studies have shown that altering the sowing dates changed the degree of infection by Orobanche spp. For example, observations in field trials on different sowing dates carried out in the International Center for Agricultural Research in the Dry Areas (ICARDA) supported the hypothesis that temperature is a key factor influencing the interaction between host and parasite (15). An early sowing date was recommended for sunflower crops in
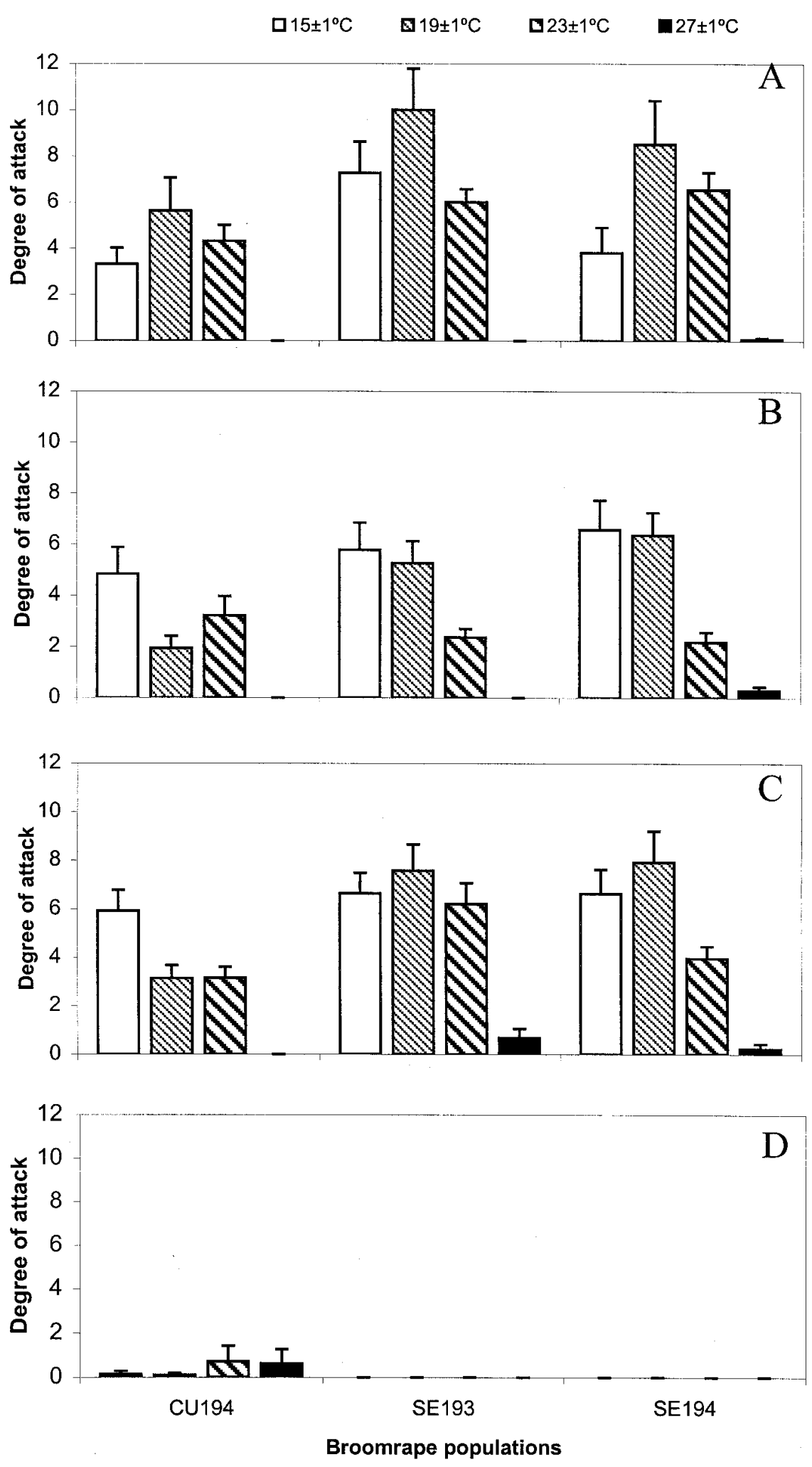

Fig. 2. Effect of temperature on the degree of broomrape attack (= number of emerged plants) on four sunflower lines (A, KA-41, B, HA-89, C, RHA-273, and D, J-8281) inoculated with three populations of Orobanche cumana. Bars represent standard errors. 
broomrape-infested areas under Mediterranean conditions using the highly susceptible confectionery-type cv. Gigante (1). In contrast, resistance of sunflower cv. Sunbred254 was not expressed in early planting (5).

In our study, infection was lowest for all the populations at the highest temperature tested $\left(27^{\circ} \mathrm{C}\right)$, but the same sunflower lines showed variable results with different populations of $O$. cumana at three lower temperatures (Figs. 1 and 2). Moreover, different sunflower lines responded differently to the same population of $O$. cumana. For example, with the population CU194, the highest degree of attack for KA-41 occurred at moderate temperature $\left(19^{\circ} \mathrm{C}\right)$; whereas, for HA-89 and RHA-273, it was at $15^{\circ} \mathrm{C}$, suggesting that the interaction between sunflower and $O$. cumana can be complex.

Recommendations for sunflower planting dates should include results for specific genotypes and seasonal temperatures. The observed delay in broomrape emergence at lower temperatures agrees with the observations on $O$. aegyptiaca infecting eggplant and tomato (2) and suggests that evaluations of early plantings should not underestimate possible inconspicuous infections by broomrape plants that do not emerge but may impair the host crop. Further studies on the dependency of sunflower germ plasm upon environmental conditions should be conducted before recommendations of planting dates are given as a method of controlling broomrape of sunflower.

\section{ACKNOWLEDGMENTS}

We wish to thank J. Cobos and T. Olmo for technical assistance and J. Ruso and Scott Grayburn for editorial assistance.

\section{LITERATURE CITED}

1. Castejón-Muñoz, M., Romero-Muñoz, F., and García-Torres, L. 1993. Effect of planting date on broomrape (Orobanche cernua Loefl.) infections in sunflower (Helianthus annuus L.). Weed Sci. 33:171-176.

2. Eizenberg, H., Tanaami, Z., Ovdat, N., Rubin, B., and Jacobsohn, R. 1998. Effect of seasonal conditions on host-parasite relationship in Orobanche crenata and O. aegyptiaca. Pages 187-192 in: Current Problems of Orobanche Researches. K. Wegmann, L. J. Musselman, and D. M. Joel, eds. Proc. 4th. Int. Workshop Orobanche, Albena, Bulgaria.

3. Foy, C. L., Jacobsohn, R., Bohlinger, B., and Jacobsohn, M. 1991. Seasonal behavior of broomrape species as determined by host range and environmental factors. Pages 454457 in: Parasitic Flowering Plants. J. K. Ransom, L. J., Musselman, A. D. Worsham, and C. Parker, eds. Proc. 5th Int. Symp. Parasitic Weeds, CIMMYT, Nairobi, Kenya.

4. González-Torres, R., Jiménez-Díaz, R. M., and Melero-Vara, J. M. 1982. Distribution and virulence of Orobanche cernua in sunflower crops in Spain. Phytopathol. Z. 104:78-89.

5. Ish-Shalom-Gordon, N., Jacobsohn, R., and Cohen, Y. 1994. Seasonal fluctuations in sunflowers resistance to Orobanche cumana. Pages 351-355 in: Biology and Management of Orobanche. A. H. Pieterse, J. A. C. Verkleij, and S. J. Ter Borg, eds. Royal Tropical Institute, Amsterdam, The Netherlands.

6. Joel, D. M. 1988. Orobanche cumana-a new adventive weed in Israel. Phytoparasitica $16: 375$.

7. Melero-Vara, J. M., Domínguez, J., and Fernández-Martínez, J. M. 1989. Evaluation of differential lines in a collection of sunflower parental lines for resistance to broomrape (Orobanche cernua) in Spain. Plant Breed. 102:322-326.

8. Melero-Vara, J. M., García-Pedrajas, M. D., Pérez-Artés, E., and Jiménez-Díaz, R. M. 1996. Pathogenic and molecular characterization of populations of Orobanche cernua Loefl. from sunflowers in Spain. Pages 677683 in: Proc. 14th Int. Sunflower Conf. Beijing-Shenyang, P. R. China. Int. Sunflower
Assoc. Paris, France.

9. Musselman, L. J. 1994. Taxonomy and spread of Orobanche. Pages 27-35 in: Biology and Management of Orobanche. A. H. Pieterse, J. A. C. Verkleij, and S. J. Ter Borg, eds. Royal Tropical Institute, Amsterdam, The Netherlands.

10. Nandula, V. K., Foy, C. L., and Westwood, J. H. 1996. Environmental influences on germination of Orobanche. Pages 411-416 in: Advances in Parasitic Plant Research. M. T. Moreno, J. Cubero, D. Berner, D. Joel, L. J. Musselman, and C. Parker, eds. Proc. 6th Int. Symp. Parasitic Weeds, Córdoba, Spain.

11. Panchenko, A. Y. 1975. Early diagnosis of broomrape resistance in breeding and improving seed production of sunflower (in Russian). Viestnik, Sielkskojosia Stvennog Nauki 2:107-115.

12. Parker, C., and Riches, C. R. 1993. Parasitic Weeds of the World: Biology and Control. CAB International, Wallingford, U.K.

13. Pujadas, A., and Thalouarn, P. 1998. Orobanche cernua Loefl. and Orobanche cumana Wallr. in the Iberian Peninsula. Proc. 6th Mediterr. Symp. Montpellier, France. EWRS:159-160.

14. Saavedra del Río, M., Fernández-Martínez, J. M., and Melero-Vara, M. 1994. Virulence of populations of Orobanche cernua Loefl. attacking sunflower in Spain. Pages 139-141 in: Biology and Management of Orobanche. A. H. Pieterse, J. A. C. Verkleij, and S. J. Ter Borg, eds. Royal Tropical Institute, Amsterdam, The Netherlands.

15. Sauerborn, J. 1989. The influence of temperature on germination and attachment of the parasitic weed Orobanche spp. on lentil and sunflower. Angew. Botanik 63:543-550.

16. Skoric, D. 1988. Sunflower breeding. Uljarstvo 25:40-45.

17. Vrânceanu, A. V., Tudor, V. A., Stoenescu, F. M., and Pirvu, N. 1980. Virulence groups of Orobanche cumana Wallr., differential hosts and resistance source genes in sunflower. Pages 74-82 in: Proc. 9th Int. Sunflower Conf. Torremolinos, Spain. Inst. Nacional de Investigaciones Agraria, Madrid, Spain. 